\title{
Hardware Materials in Molten Carbonate Fuel Cell: A Review
}

\author{
Ling Chen ${ }^{1}$ Chao-Yi Yuh ${ }^{1}$
}

Received: 11 August 2016/Revised: 10 November 2016/Published online: 14 February 2017

(C) The Chinese Society for Metals and Springer-Verlag Berlin Heidelberg 2017

\begin{abstract}
The high-temperature molten carbonate fuel cell is an ultra-clean and highly efficient power generator. It is operated at $\sim 550-650{ }^{\circ} \mathrm{C}$, which is considered optimal in facilitating fast fuel cell reaction kinetics, utilizing waste heat efficiently, and allowing use of commercial construction materials. Commercial MW-size (mega watt) power plants of FuelCell Energy products have already been deployed worldwide. Metallic hardware materials are extensively utilized and may experience high-temperature reducing and oxidizing atmospheres in the presence of molten alkali carbonate electrolyte. Material selections are founded on many decades of focused research and development and field experience. Results to date show that the baseline stack module materials meet 5-year life goal and BOP (balance of plant) construction materials meet 20-year life goal. Material durability is well understood, and solutions are available to further extend the durability. This paper will review hardware materials experience and development approaches that would further reduce cost and extend life.
\end{abstract}

KEY WORDS: Molten carbonate fuel cell; High-temperature materials; Corrosion

\section{Introduction}

The high-efficiency, ultra-clean Direct FuelCell ${ }^{\circledR}$ (DFC) power plant of FCE is based on high-temperature internalreforming molten carbonate fuel cell (MCFC) technology. FCE has been developing DFC technology since the mid1970s and has grown to a fully integrated global fuel cell company developing, manufacturing, selling, installing, and servicing complete commercial stationary distributed generation power plants. FCE has been commercially deploying the DFC products since 2003. The DFC products can meet the power requirements of a wide range of commercial and industrial customers including wastewater treatment plants, telecommunications/data centers, manufacturing facilities, office buildings, hospitals, universities,

Ling Chen

lchen@fce.com

1 FuelCell Energy, Inc., Danbury, CT 06813, USA mail processing facilities, hotels and government facilities, as well as in-grid support applications for utility customers, utilizing a variety of fuels such as natural gas, biogas, coal gas, diesel, propane [1]. Currently, DFC plants are generating power at more than 50 locations worldwide, with more than $300 \mathrm{MW}$ of generation capacity installed or in backlog. More than 4 billion kilowatt hours of ultra-clean power have been generated by DFC plants so far.

The MCFC operates at a temperature range of $550-650{ }^{\circ} \mathrm{C}$. This temperature level is optimal for allowing the use of commercially available, cost-effective, heat-resistant alloys such as stainless steels that can be easily fabricated into power plant components by low-cost processes [2]. The heart of the MCFC power plants is fuel cell stacks. Each stack is made of several hundred individual cell packages. Each cell package is composed of active components (anode, cathode, electrolyte matrix) and cell hardware (bipolar plate, current collectors, seal area), as illustrated in Fig. 1. Conventional austenitic stainless steels are extensively used [2-8], contributing to more than $50 \%$ 


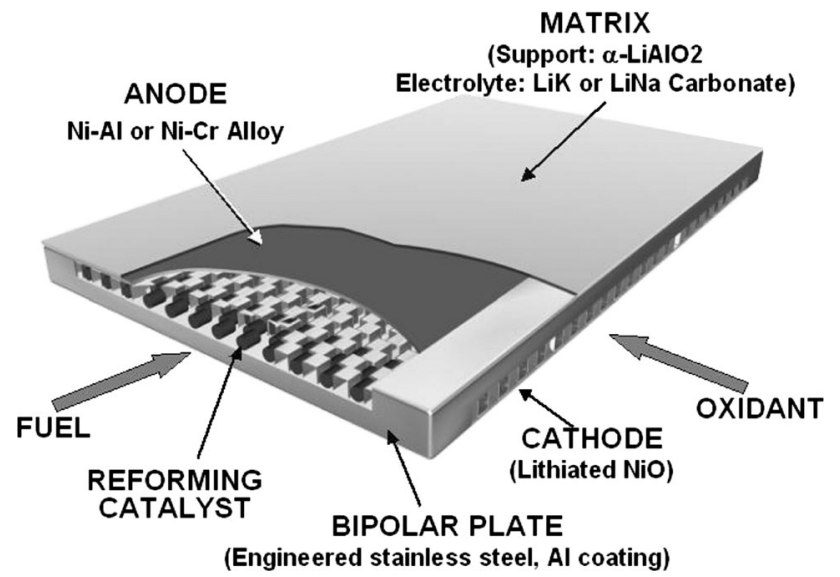

Fig. 1 Carbonate fuel cell construction: low-cost stainless steel ironbase alloys are used for cell hardware construction

in weight of a stack. A DFC power plant also contains stack module and balance-of-plant (BOP) hardware; stainless steels are also extensively used [2-8]. The environment that these alloys are exposed to include reducing gas (low oxygen partial pressure, $\sim 10^{-20} \mathrm{~atm}$ ) in the fuel stream or oxidizing gas (high oxygen partial pressure, $>0.1 \mathrm{~atm}$ ) in the oxidant stream. The fuel gas stream could also be high in carbon activity. Some components (such as the bipolar plate or thin-wall bellows) could also experience a dualatmosphere condition where it is exposed to both oxidizing (on the one side) and reducing (on the other side) gas streams. The cell hardware also experiences thermo-mechanical stress, thermal and gas atmosphere transients, and possibly gas contaminants. Metallic corrosion, especially in the presence of molten carbonate, represents an important factor that controls both plant performance and lifetime. FCE's commercial DFC stacks have successfully achieved more than 5-year service in field operation. This paper will review design and selection considerations and FCE experience with stack hardware and BOP materials in DFC.

\section{Cell Hardware Materials}

\subsection{Anode/Cathode Current Collectors and Bipolar Plate}

Numerous austenitic stainless steels have been extensively evaluated for use in DFC packages where molten-salt accelerated oxidation (hot corrosion) occurs $[5,6]$. Upon reaction with a thin creeping film of the molten alkali carbonate salt, a multi-layered, alkali-doped corrosion scale forms a porous outer-layer of $\mathrm{LiFeO}_{2}$ and a relatively dense underlying layer of mixed $\mathrm{Fe}-\mathrm{Cr}$ oxide or $\mathrm{LiCrO}_{2}$. Soluble corrosion products, such as $\mathrm{K}_{2} \mathrm{CrO}_{4}$ or $\mathrm{Na}_{2} \mathrm{CrO}_{4}$, can also form in an oxidizing atmosphere. Moreover, $\mathrm{Mn}$ alloy impurity could form $\mathrm{Li}_{2} \mathrm{MnO}_{3}$, and $\mathrm{Ni}$ and $\mathrm{Co}$ in the alloys could be oxidized to form $\mathrm{Li}_{x} \mathrm{Ni}_{1-x} \mathrm{O}$ and $\mathrm{LiCoO}_{2}$. The ohmic resistivity of the oxide scale in the currenttransmitting active area could reduce power output and needs to be minimized. In general, a more corrosion-resistant oxide scale has a higher ohmic resistivity. The electric ohmic conductivity of the oxide scale is related to the alloy composition. Alloys with more than $20 \mathrm{wt} \% \mathrm{Cr}$ show significantly higher oxide ohmic resistance than those with less than $20 \mathrm{wt} \% \mathrm{Cr}$, suggesting that the ohmic conductivity is mostly determined by the inner Cr-containing corrosion layer [3]. Alumina-forming alloys, although having significantly better corrosion resistance than chromia-forming ones, have been shown to cause unacceptably high ohmic contact resistance due to the much higher alumina-scale resistivity. The hot corrosion of stainless steel in molten carbonate exhibits an active-passive process: fast active corrosion under reducing atmosphere whereas somewhat passive corrosion under oxidizing atmosphere [6]. The hot corrosion rate is also strongly influenced by the amount of electrolyte present on the surface. The cell design that can minimize electrolyte movement to the hardware can be predicted to reduce hot corrosion attack. Hot corrosion also contributes to electrolyte loss from the cell active components due to the formation of alkali-containing oxide corrosion products or electrolyte absorption by the porous oxide scale. The materials should also maintain mechanical integrity by having not only adequate corrosion resistance but also proper thermal expansion coefficient and strength. Therefore, selection of cell hardware alloys needs to take into account numerous aspects: corrosion, oxide conductivity, electrolyte loss, mechanical properties, cost, and cell design. FCE has confirmed corrosion stability of the selected cell hardware alloys in field product stacks

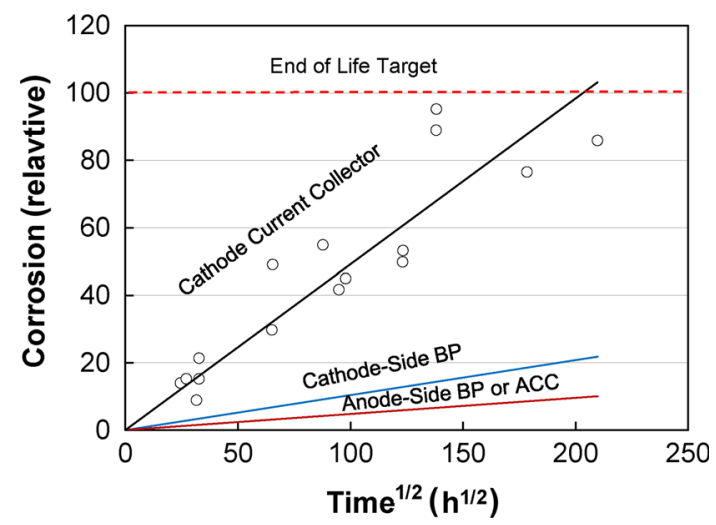

Fig. 2 DFC baseline cell hardware. $C C C$ cathode current collector, $B P$ bipolar plate, $A C C$ anode current collector: $>5$-year $(40,000 \mathrm{~h})$ durability demonstrated 
operated for more than 5 years (Fig. 2). The corrosion rate is parabolic, consistent with diffusion-controlled corrosion law.

As shown in Fig. 2, the cathode current collector (CCC) has a higher corrosion rate than the bipolar plate (BP) and the anode current collector (ACC). In order to extend life further, FCE has developed a protective coating that has demonstrated significantly improved corrosion resistance, as shown in Fig. 3. The uncoated CCC side showed hot corrosion after $\sim 5700 \mathrm{~h}$ of stack testing, while the coated side essentially eliminated the corrosion attack. The actual service life of CCC without coating is 5 years as shown in Fig. 2, while the one-sided coating should last twice longer (10 years), since the total amount of corrosion is reduced by half. The selected surface coating is projected to extend the CCC service life beyond 10 years. It has also been demonstrated to significantly reduce electrolyte loss by $\sim 60 \%$ due to much less stainless steel lithiation reaction with electrolyte.

The anode-side environment (particularly the fuel exit) will have faster active hot corrosion than the cathode side in the presence of electrolyte film. Thermodynamically stable Ni coating has been used to provide protection. The $\mathrm{Ni}$ coating is applied by either electroplating or cladding. However, such Ni-coating processes are expensive. Furthermore, Ni coating promotes carburization by facilitating fast carbon diffusion to the substrate from the high-carbon activity fuel gas. FCE has selected an uncoated, low-cost stainless steel for anode current collector which has shown acceptable corrosion resistance for $>5$-year service life, as shown in Fig. 2. Steps are taken in the cell design to prevent electrolyte creepage to the anode cell hardware to prevent fast corrosion.

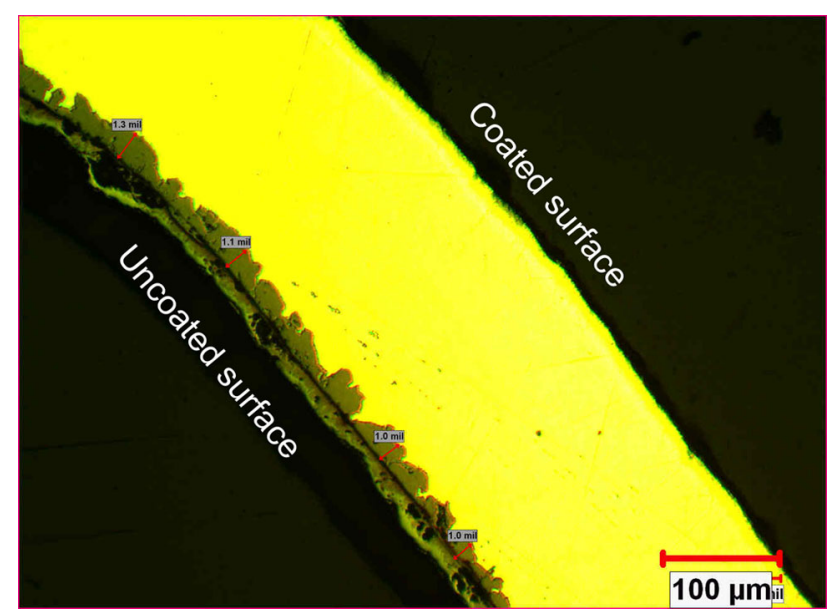

Fig. 3 Advanced surface protective coating demonstrated significantly improved hot corrosion resistance (in $\sim 5700$-h stack test). Coating approach can project $>10$-year service life
The bipolar plate is exposed to the reducing anode gas on the one side and the oxidizing oxidant gas on the other side (dual-atmosphere). It was observed about three decades ago that the medium-Cr 316 stainless steel (with $\mathrm{Cr}$ content between 16 and $18 \mathrm{wt} \%$ ) experienced anomalously fast corrosion on the oxidant (cathode) side, attributed to the hydrogen diffusion from the anode side to the cathode side across the thin stainless steel sheet and subsequently partially reducing the oxide scale and/or reacting with the oxygen to form water vapor (within the cathode-side oxide scale), disrupting the formation of a dense protective oxide layer [9]. This accelerated attack is more pronounced for medium Cr SS (such as 316) than for higher $\mathrm{Cr}$ (such as 310). Therefore, proper evaluation of alloys under a dualatmosphere condition is needed for evaluating candidate bipolar-plate materials. As shown in Fig. 2, the FCE selected bipolar-plate alloy has demonstrated high dualatmosphere corrosion resistance.

Material mechanical properties (creep and ductility) should be carefully assessed to assure sufficient longterm mechanical stability of the cell hardware. Due to inherent temperature variations during operation as a result of non-uniform current density distribution and thermal generation, high thermal stresses $(>5 \mathrm{ksi}$ ) could exist at stack hotter locations. Gradual bipolar-plate dimensional growth (creep) due to such stresses could lead to decreasing gas manifold sealing efficiency. Precipitate phases tend to form in stainless steels and indeed were observed in MCFC during long-term use [2], including carbides from residual carbon impurity or carbon intake from the high-carbon activity fuel, and other secondary phases (such as $\sigma, \eta$, and $\chi$ ) from the alloy elements such as $\mathrm{Fe}, \mathrm{Cr}, \mathrm{Nb}$, Ti $[10,11]$. The precipitation of carbide phases sensitizes the alloys (sensitization), accelerating grain-boundary corrosion [12]. In general, a higher $\mathrm{Cr}$ content can promote the precipitation, while a higher $\mathrm{Ni}$ content retards it [10]. The formation of the $\sigma$ phase is accelerated by temperature, as observed in $>5$-year operated field stacks (Fig. 4). Cold working also appears to promote such phase transformation, likely due to the preferred precipitate nucleation at crystallographic defect locations (Fig. 5). The formation of all these precipitates causes embrittlement and creep strength reduction. Under sufficiently high mechanical stress, the embrittled alloys may even fracture (stress corrosion cracking) [12]. Approaches to reduce thermal stress include adjusting the cell design and operating conditions. Material changes to retard such undesirable precipitation and improve creep strength include grain-size increase adjustment $[11,13]$, as demonstrated in Fig. 6. Other strengthening mechanisms such as precipitation hardening should also be explored. 

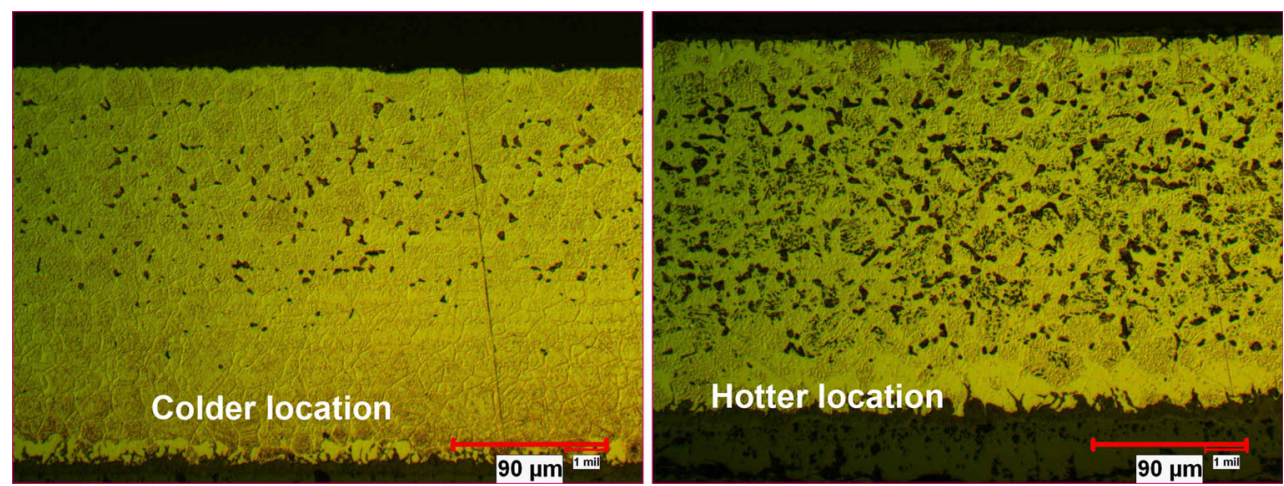

Fig. 4 DFC field stack operated for $>5$ years showing the formation of $\sigma$ phase accelerated by temperature
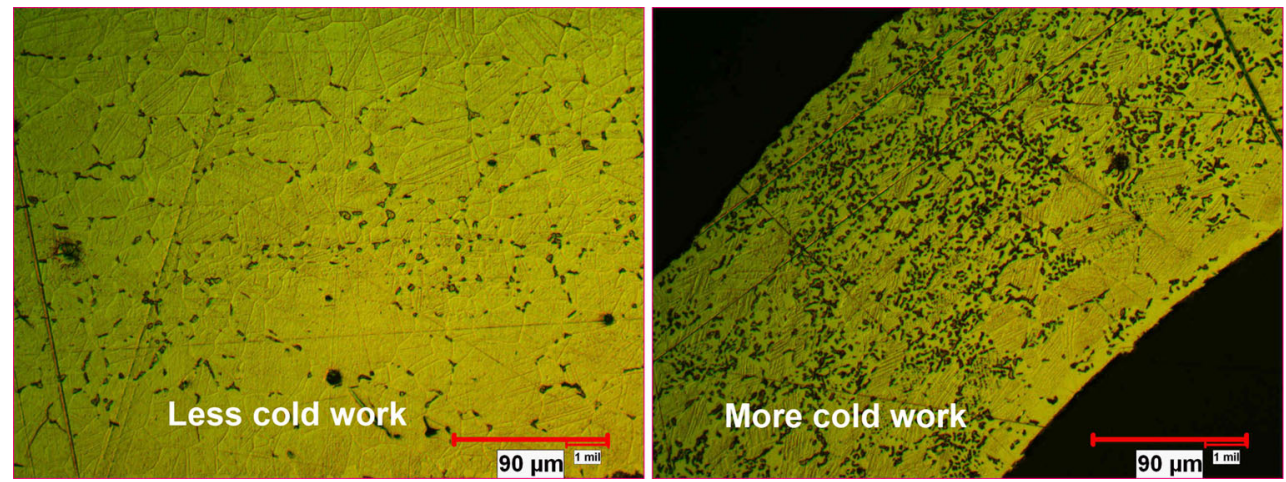

Fig. 5 DFC field stack operated for $>5$ years showing the formation of $\sigma$ phase accelerated by cold work
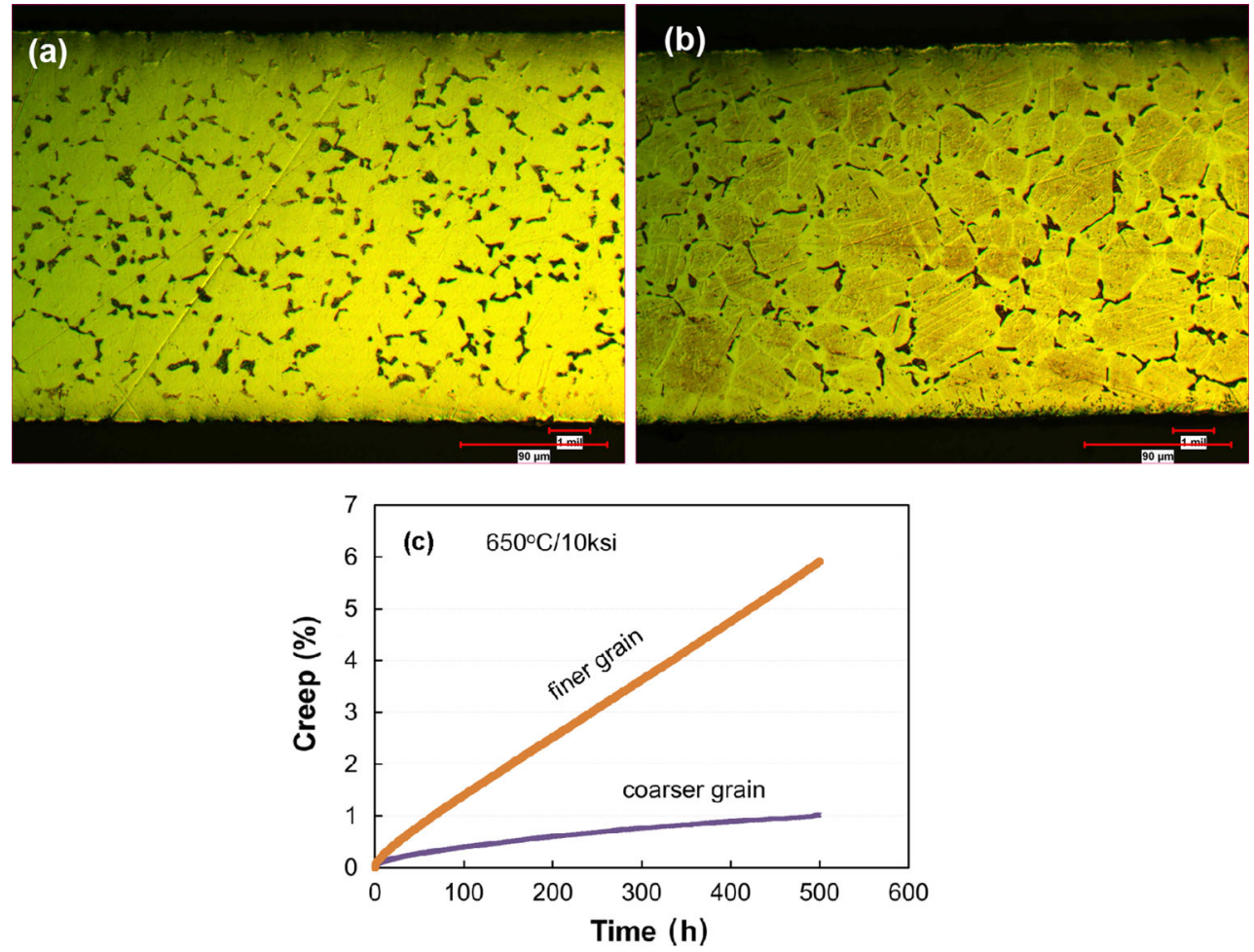

Fig. $6 \sigma$-phase precipitation in a finer-grain and $\mathbf{b}$ coarser-grain austenitic stainless steel heat treated at $750{ }^{\circ} \mathrm{C}$ for $1700 \mathrm{~h}$, $\mathbf{c}$ creep strength improvement with coarser-grain structure 


\subsection{Wet Seal Material}

The cell-perimeter seal area simultaneously experiences reducing and oxidizing environments [14]. MCFC seal is provided by a molten electrolyte-filled matrix (wet seal). Aluminized coating has widely been used and could be made via thermal spray (flame spray, HVOF, etc.), pack cementation, physical vapor deposition (PVD), chemical vapor deposition (CVD), ion vapor deposition (IVD), slurry painting, or melt dipping. Some of these processes may require heat treatment to develop an adequate porefree diffused $\mathrm{Fe}-\mathrm{Al}$ intermetallic layer. Higher-temperature coating processes such as thermal spray or pack cementation may cause undesirable thermal distortion on thin metallic sheet. FCE has adopted a cost-effective aluminizing coating process that has shown excellent protection for the substrate stainless steel, demonstrated in longterm $>5$-year operation field stacks $[15,16]$ (Fig. 7).

\section{Stack, Module, and BOP Alloys}

The module and BOP hardware materials experience temperatures between $200{ }^{\circ} \mathrm{C}$ and $900{ }^{\circ} \mathrm{C}$ and can experience various thermal and gas atmosphere transients during operation. The materials are generally less exposed to molten electrolyte and experience less hot corrosion. Nevertheless, excessive oxide spallation may cause undesirable debris formation and fouling. Another important consideration is cost. BOP materials contribute a significant portion of the total power plant material cost. For lower temperature service $\left(<600{ }^{\circ} \mathrm{C}\right)$, lower-cost standard ferritic stainless steels may be acceptable. Standard high-Cr austenitic stainless steels may be useable for up to $750{ }^{\circ} \mathrm{C}$. Although alumina-forming alloys may be useable at

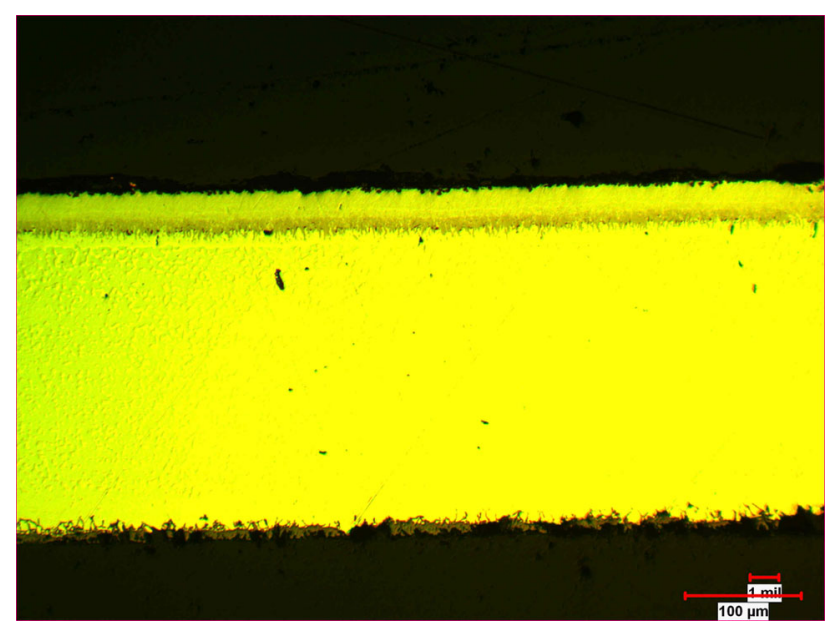

Fig. 7 Aluminized coating demonstrating excellent wet seal protection in $>5$-year field service temperatures even beyond $800{ }^{\circ} \mathrm{C}$, their high cost may prohibit usage in significant quantities. Therefore, highcost materials can only be used sparingly. FCE has accumulated extensive material experience through long-term, multi-year DFC power plant field operations. FCE has also conducted extensive long-term material tests in simulated environments; oxidation, debris formation, and mechanical properties (yield strength, ductility, and creep) have been measured for numerous heat-resistant alloys. Higher-Cr ( $>22 \mathrm{wt} \% \mathrm{Cr}$ ) stainless steels demonstrated no corrosion issue, as shown by the gas manifold in field use for $>5$ years (Fig. 8). The medium-Cr $(\sim 18 \mathrm{wt} \% \mathrm{Cr})$ stainless steels, although having a faster corrosion rate, have shown to be adequate for 20-year service for thick-walled piping/ equipment application. However, faster corrosion could occur for thin-walled material such as expandable bellow at certain locations experiencing electrolyte vapor attack (Fig. 9). Al-coated ferritic stainless steels are potential alloys to reduce cost compare to austenitic alloys. For example, medium-Cr austenitic stainless steel used for the module vessel lining has shown significant oxide debris spallation and high-Cr stainless steels significantly reduced spallation, but at a higher cost (Fig. 10). FCE has identified a low-cost Al-coated ferritic stainless steel that has demonstrated excellent corrosion and spallation resistance (Fig. 10). Stress corrosion cracking (SCC) which could lead to sudden high gas leakage was also occasionally observed (Fig. 11). A sensitized structure is developed during service. The stainless steels inherently become brittle due to high-temperature phase transformation as discussed above, and it is well known that temperature, environment, and stress are key factors contributing to SCC [12]. Therefore, thermo-mechanical stresses should be minimized to avoid such brittle failure. Moisture condensation should also be eliminated to prevent the SCC failure.

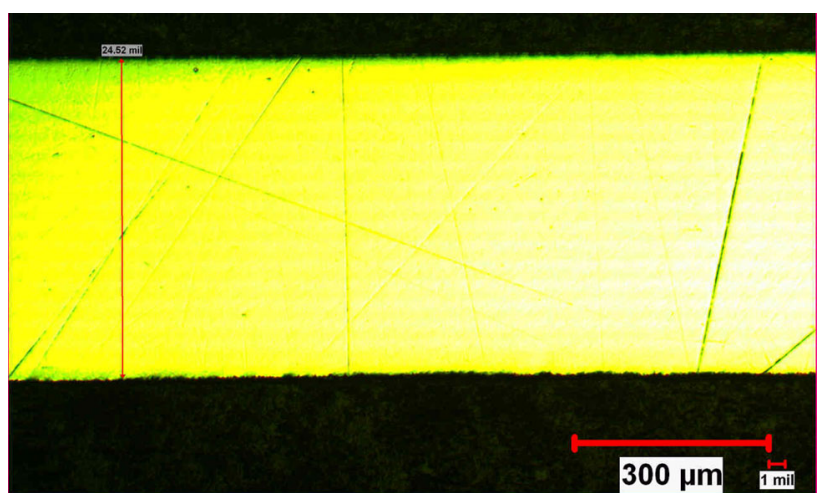

Fig. 8 High-Cr stainless steel demonstrating excellent corrosion stability as gas manifold in field stack operated for $>5$ years. According to this corrosion rate $(13 \mu \mathrm{m} / \mathrm{year})$, more than 20 -year service life can be projected 

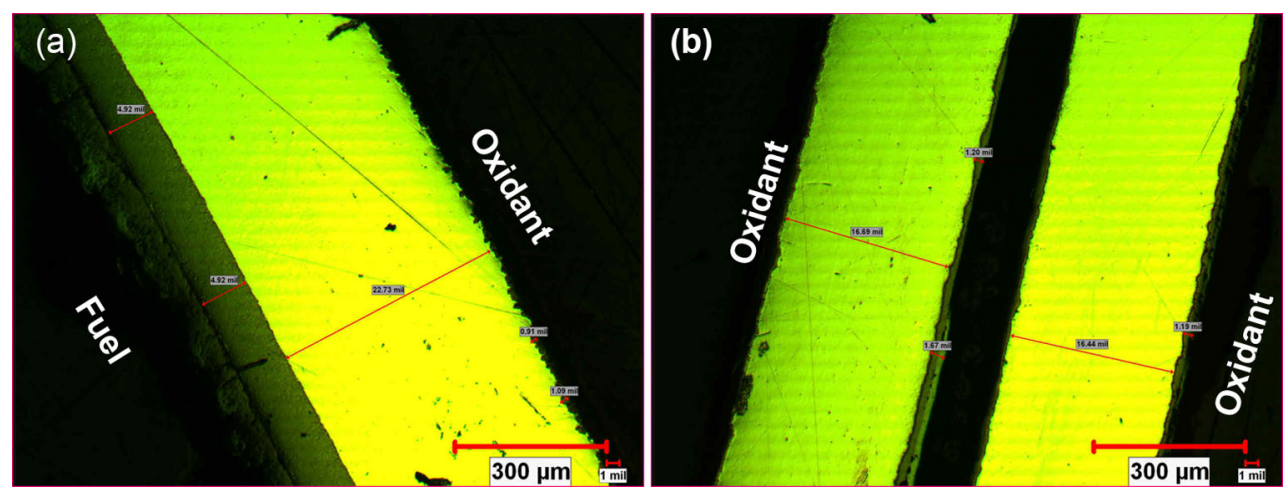

Fig. 9 Faster corrosion of medium-Cr stainless steel bellow a under fuel exit stream, whereas little corrosion of double-wall bellow $\mathbf{b}$ under oxidant exhaust stream, both after $>5$-year field service. Based on the corrosion rate shown in the figure, $>10$-year durability can be projected
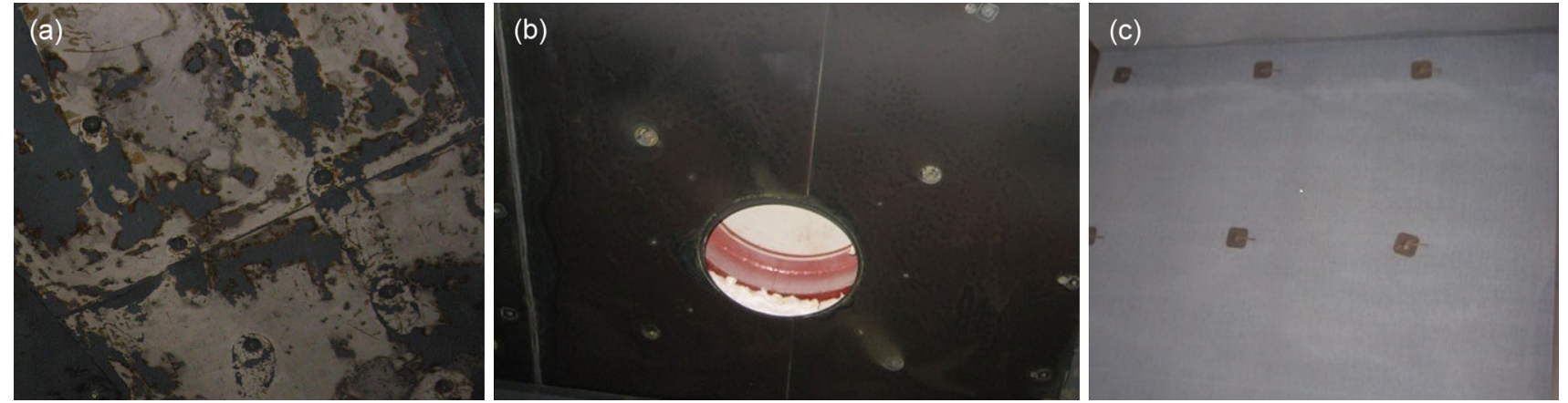

Fig. 10 a Baseline vessel lining material showing significant oxide spallation in 15,000-h operation, b higher-Cr alloy reducing spallation significantly, c low-cost Al-coated ferritic alloy also reducing spallation significantly

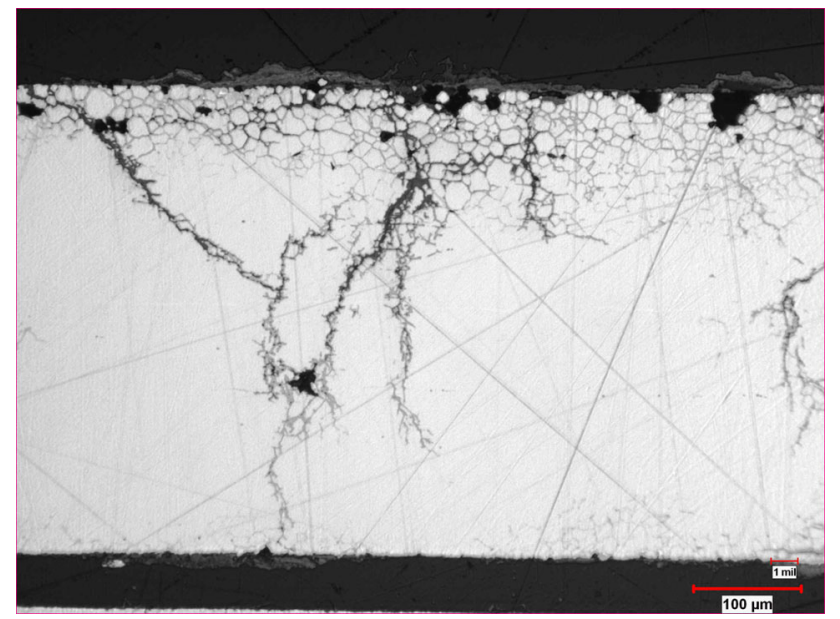

Fig. 11 Stress corrosion cracking was observed on sensitized and embrittled stainless steel (in 14,500-h field service): reduction in stress and moisture condensation can eliminate such SCC fracture

\section{Conclusion}

The selection of carbonate fuel cell materials is determined by corrosion stability, mechanical properties, and cost considerations. Heat-resistant alloys have been extensively used. The $>5$-year field operation experience confirms that the employed material solutions are robust and can achieve desired DFC commercial service life. Opportunities exist for further life extension and cost reduction.

Acknowledgements The authors would like to acknowledge FCE's technical staffs on the combined contribution to the progress reported in this paper. The authors also thank Adam Franco for performing metallographic analysis and Richard Johnsen for identifying commercial Al-coated ferritic stainless steels for high-temperature service.

\section{References}

[1] M. Farooque, H. Maru, J. Power Sources 160, 827 (2006)

[2] C. Yuh, L. Chen, A. Franco, M. Farooque, in High Temperature Corrosion and Oxidation of Materials, Materials Science and Technology (MS\&T 2013) (Montreal, Quebec, Canada, 27-31 Oct, 2013), p. 2531

[3] S. Frangini, J. Power Sources 182, 462 (2008)

[4] A. Schoeler, T.D. Kaun, I. Bloom, M. Lanagan, M. Krumpelt, J. Electrochem. Soc. 147, 916 (2000)

[5] J. Hoffmann, C. Yuh, A. GodulaJepek, Electrolyte and material challenge, in Handbook of Fuel Cells-Fundamentals, Technology and Applications, vol. 4, ed. by W. Vielstich, A. Lamm, H. Gasteiger (Wiley, Hoboken, 2003), pp. 921-941

[6] D. Shores, M. Pischke, The hot corrosion of current collector/ separators and carbonate fuel cells, eds. D. Shores, H. Maru, I. Uchida, and J. R. Selman. 3rd International Symposium 
Carbonate Fuel cell Technology (The Electrochemical Society, Pennington, NJ, 1993) PV 93-3, pp. 214-229

[7] C. Yuh, A. Hilmi, L. Chen, A. Franco, M. Farooque, ECS Trans. 41, 21 (2012)

[8] C. Yuh, M. Farooque, Materials and life considerations, in Encyclopedia of Electrochemical Power Sources, ed. by J. Garche, et al. (Elsevier, Amsterdam, 2009), p. 497

[9] Z. Yang, G. Xia, M. Walker, C. Wang, J. Stevenson, P. Singh, Int. J. Hydrogen Energy 32, 3770 (2007)

[10] T. Sourmail, Mater. Sci. Technol. 17, 1 (2001)

[11] C. Hsieh, W. Wu, Overview of intermetallic sigma phase precipitation in stainless steels. ISRN Metall. 2012, Article ID 732471

[12] A.J. Sedricks, Corrosion of Stainless Steels (Wiley-Interscience, Hoboken, 1996)
[13] P.J. Maziasz, B.A. Pint, J.P. Shingledecker, N.D. Evans, Y. Yamamoto, K.L. More, E. Lara-Curzio, Int. J. Hydrogen Energy 32, 3622 (2007)

[14] R.A. Donado, L.G. Marianowski, H.C. Maru, J. Electrochem. Soc. 131, 2541 (1984)

[15] C. Yuh, L. Chen, A. Franco, M. Farooque, review of hightemperature fuel cell hardware materials. Symposium. ASME 2010 Eighth International Fuel Cell Science, Engineering and Technology Conference (Brooklyn, New York, 14-16 June, 2010) FuelCell2010-33163

[16] J. Li, C. Yuh, T. Lucas, M. Primerano, US Patent 6372374, 16 Apr 2002 